\title{
Conflicts and Violence as Structuring Metaphors of the Santo Daime, a Religious and Environmental Movement in the Brazilian Amazon
}

In this article I will show how conflicts and violence have influenced the development of Santo Daime, a religious and environmental movement in the Brazilian Amazon. By discussing three interrelated aspects (1) Violence and conflict in Santo Daime history; (2) Ideas about good and bad spirits; and (3) Santo Daime environmentalism, I will show the relatedness between the members' experiences of conflicts and violence in their history as rubber tappers and conflicts and violence as structuring metaphors in their daily ritual practices.

Santo Daime was founded in the early 1930s in Rio Branco, the state capital of Acre (located in the southwestern corner of the Brazilian Amazon) by Irineu Serra, a black man originally from Northeastern Brazil who came down to the area to work as a rubber tapper during the years of the rubber boom between 1850 and 1920. While working in the Amazonian forests, Irineu Serra came into contact with ayahuasca, a psychoactive brew traditionally used by local Amerindian and caboclo shamans. Eventually his encounter with this brew resulted in the development of a new religion based on the psychoactive experiences that he had received when drinking the brew.

Present members claim that this brew, which they call daime, has the capacity to 'open up' people and make them receptive to the spiritual world. According to the members, this world is even more real than that of everyday life, which they refer to as 'the world of illusion' (o mundo da illusão). Further, daime is said to have an extraordinary power to heal various kinds of illnesses, be they illnesses which are common in the region, like malaria, hepatitis, and asthma, or more deadly diseases like AIDS and cancer.

1 Caboclos are the descendants of a mixed population of Amerindians, Europeans and Africans, living along the waterways of the Amazon River. 
Members drink the brew during highly structured, almost military style rituals in which they dance (or sit down quietly to concentrate) for up to 8 to 10 hours. During such events they also sing from a large body of Santo Daime hymns, which play a crucial role as the content of these hymns is said to direct participants during the peak moment of the ritual experience which is called the miração. Miração is a word derived from the Portuguese verb mirar (to see) and ação (action). Although it is possible to speak of this experience in terms of a kind of vision, members claim that the miração is far from any form of 'static seeing'. Rather, it is said to be an interactive experience during which people interact with what they are seeing. As an old woman said: 'We do not "see" things, we take part in what we see.'

What people experience during the miração is said to have a tremendous effect on their self-understanding. People often claim that the miração has brought about transformative insights, changing their lives and the way they relate to other human beings and to the world at large. Further, the miração is also said to contribute to an 'environmental awakening', that is, an enhanced interest in caring for nature.

Although unique, Santo Daime religion is often described as a syncretic religion. This is so because Santo Daime members creatively mix ideas and practices from Amerindian spiritual traditions with those of Catholicism, Brazilian Spiritism, and Afro-Brazilian traditions. In recent years, so-called New Age ideas and practices and those of the environmental movement have also had a major impact on Santo Daime religion.

The first Santo Daime members were caboclo, the majority of whom had worked in the rubber industry. In the 1970s young people (many of them part of the so-called 'Hippie Movement') from Brazilian and Latin American cities also began to join the movement. Later when some of these youths returned to their home towns they began to set up affiliated Santo Daime centres. The first urban centre was established in the early 1980s in Rio de Janeiro and has been followed by several more affiliated Santo Daime centres all over Brazil. ${ }^{2}$

In the mid 1980s a decision was taken to move the mother community from Rio Branco into the interior of the Amazonian rainforest. With the establishment of a new village along the Mapiá River (an affluent of the Purús River, which in its turn is a tributary to the Amazon River), a new phase of the movement's development began. More people steadily joined the movement, so that from 150 members in the mid-1980s, the movement 
has today, only in Brazil, well over 10,000 members. Around 800 of these live in the present mother community called Céu do Mapiá (Heaven of Mapiá). Besides the permanent residents (consisting of $70 \%$ caboclos and $30 \%$ former urban dwellers), the village is also regularly visited by both members and non-members whose main purpose for visiting the community is that they believe that daime will be able to cure them from whatever kind of illness they are suffering from.

During the 1990s Santo Daime began to expand outside Brazil, and today there are centres all over Europe (in the Netherlands, Spain, Portugal, Germany, Switzerland, Austria, Italy, France, and Great Britain). Centres have also been set up in Japan, Argentina, and the United States, including Hawaii.

Hand in hand with this geographical expansion, there has also been an expansion into new ideological arenas. What was once a small local, religious movement has, during the last twenty years, turned into an environmental movement with global aspirations. An important step in this direction was the initiative taken by some of the urban members in forming a protected environmental area around Céu do Mapiá, a so-called National Forest. In 1988 the National Forest of Purús was created (256,000 hectares) and the following year, the National Forest of Mapiá-Inauiní (311,000 hectares). In recent years, the members have worked hard to turn Céu do Mapiá into an ecovillage that could serve as a model community, showing both other local people and government representatives that it is possible to live a sustainable life within Amazonian rainforest without destroying the nature.

The focus on environmentalism, which has intensified further during the last years, has resulted in a variety of different eco-social projects within the village. In 2002, for example, there were more than 40 ongoing projects, aiming at forest preservation, environmental education, and the production of alternative forest medicine and food, including dried fruit processing. The majority of these projects are funded by non-religious agencies from all over the world, although the villagers have also benefited from donations from affiliated Santo Daime centres.

In order to understand the present development of the Santo Daime movement, I argue that we have to take a closer look at the kind of violence and conflict that has dominated the history of the caboclos, the majority of whom were rubber tappers in a society dominated by unequal and often brutal socioeconomic conditions. By exploring members' perception of violence and conflict, I will show how these have been used as structuring metaphors in Santo Daime ritual. I will also show how these perceptions 
have been crucial in shaping the way members talk about and deal with spirits and how they regard themselves as caboclo warriors (caboclo guerreiros) who are in the front line of a spiritual battle (batalha) against evil, which is today also formulated in terms of a struggle against the global destruction of the environment. I will also demonstrate how the threat of conflict and violence has contributed to the development of a particular kind of Santo Daime morality, which today lies at the heart of the members' environmental commitment.

\section{Illness and Structural Violence}

Suffering, misery, and illness among the world's poor have often been related to the prevalence of so called 'structural violence' (Farmer 2003, Scheper-Hughes 1992). The term 'structural violence' is however not that easily defined. When social scientists use it they seem to include everything from overt physical violence (such as wars, torture, and killings) to more 'veiled' forms of violence (as when asymmetrical power relations generate extreme poverty and social and economical conditions that threaten to devastate the lives of the poor).

Regardless of how we define the term, it is clear that the local Amazonian population (be they Amerindians or caboclos) have been victims of structural violence for a long time. Amazonia's violent and cruel colonial past which resulted in the enslavement and extermination of millions of Amerindians, is well-known to the general public. However, even after the colonial period, local Amazonians have been brutally exploited, especially during the rubber boom and the years after it. It would be accurate to refer to these people as 'victims' (because many of them were really victims of larger and more powerful economical and political forces), but this is far from the whole picture. More than being merely passive victims, the local Amazonian people have also done their best to accommodate, respond, and oppose the forces causing affliction, suffering, and illness.

The emergence of a particular kind of healing tradition based on the use of ayahuasca in treating illnesses may be viewed as one such response. Peter Gow, writing about ayahuasca shamanism in the Amazon region, has even suggested that the use of ayahuasca in healing contexts is not such an ancient Amerindian tradition as social scientists normally think (Gow 1994). Instead, he claims that it probably has a much more recent origin and he locates the development of ayahuasca shamanism in the early missionary stations where he claims it evolved as a way to deal with the 
epidemic illnesses that plagued the local population during the colonial period. When these missions later became the embryo of towns during the rubber era, the practice of ayahuasca shamanism became even more intensified. Later, the violent and exploitative rubber industry put an enormous stress on the local population, and this in turn seems to have led to a further increase in the use of ayahuasca in healing contexts. In this vein, Gow argues that ayahuasca shamanism is above all a tradition that developed in 'urban' contexts, and it was only later that is was exported from the towns to more isolated indigenous Amerindians (1994: 91). If his claim is accurate, this would explain why ayahuasca shamanism is absent among 'those few indigenous peoples who were buffered from the processes of colonial transformation caused by the spread of the rubber industry in the region' (Gow 1994: 91). If ayahuasca shamanism is related to the development of a caboclo culture and society, it explains some seemingly contradictory statements often made by local Amazonians. For example, the common claim among Amerindians that caboclo/mestizo shamans are more powerful than their own native shamans, as well as similar statements made by caboclos/mestizos, that ayahuasca shamanism was invented by rubber tappers (Gow 1994: 97; Luna 1986: 31; MacRae 1992).

Although Gow's challenging interpretation is quite difficult to substantiate primarily due to a lack of historical evidence, nevertheless, it does contain the interesting implication that the development of ayahuasca shamanism may be located within the context of the formation of the caboclo culture and society. If ayahuasca shamanism is viewed as having evolved as a response to the lived experience of illness and psychological stress that accompanied the violent colonial transformation of the indigenous population of Amazonia, it opens up a more complex and dynamic understanding of the healing tradition, based on the use of ayahuasca, that appeared in a more organised 'movement' form in the early 1930s.

The years following the rubber boom were extremely hard on the rubber tappers because they were forced to seek new means of subsistence. When the price of Brazilian rubber fell drastically in the 1920s (it was undermined by higher yielding rubber plantations in Southeast Asia), the once flourishing Brazilian rubber industry soon collapsed.

Even though some of the rubber tappers managed to stay on in the forests, making a living on scarce resources, relying upon swidden cultivation, hunting, and fishing, many of them were more or less forced to emigrate to the cities. This was especially so with the many Northeasterners who had just recently arrived in the region to work as rubber tappers, escaping the starvation and the hardships that followed the two big droughts 
in the Northeast in 1877 and 1889. Not well-equipped for surviving in the Amazon forest and without any means of generating an income, many of these Northeasterns had no other option than to seek new means of survival in the cities. However, working opportunities in the town were far from abundant and many of them had to survive on subsistence farming in and around the towns.

This was also the fate of Irineu Serra, the first leader of the Santo Daime movement. However, unlike many of his compatriots, Irineu Serra soon got a job in the army and for three years he worked in the forests for the Federal Government, demarcating the borders of Acre which established the frontier between Brazil, Bolivia and Peru (Fróes 1986: 32).

While working in the forests close to the Peruvian boarder, Irineu Serra learned about ayahuasca. After passing through an initiation period, a female spirit appeared in one of his visions, convincing him that he had a special mission and that he was about to receive spiritual messages in the form of hymns. The spirit, whom he later identified as both the Queen of the Forest and Virgin Mary, also encouraged him to rename ayahuasca and call it daime, a name stemming from the Portuguese verb dar, to give, which refers to the spiritual invocations that should be used when drinking the brew, such as Dai-me Amor, Dai-me Luz, Dai-me Força (Give me Love, Give me Light, Give me Strength). The spirit also taught him that daime had a special healing power and that the brew contained a teaching spirit (um professor) which could reveal secrets about the spiritual world. In 1940 Mestre Irineu (as his members later began to call him) established his first Santo Daime centre in the town of Rio Branco, a centre that soon attracted the attention of the local people, many of whom were poor and unable to pay for pharmaceuticals and clinical treatments.

In the light of Mestre Irineu's background in the military, it is perhaps not a coincidence that the rituals that he developed were highly ordered events, characterised by an almost military strictness. Apart from the drinking of daime, which plays a crucial role, the singing of hymns and the dancing in sex- and age-divided groups are also important characteristics of the Santo Daime rituals. As a sign of commitment the followers use the farda, a special kind of ritual dress. ${ }^{3}$ Even the very term farda is used in mili-

3 During some rituals the members use the 'blue dress' (farda azul). For females (women and young girls), this involves navy blue skirts, white blouses, stockings, and shoes, and a navy blue tie. For males (men and young boys), navy blue pants, white shirts, stockings, navy blue or black shoes, and a black tie. The farda azul resembles the school uniform worn by children in Brazilian governmental schools. 
tary contexts, denoting military dress. Due to the custom of using the farda, members often refer to themselves as fardados (i.e. dressed members).

Another characteristic of Santo Daime ritual is the use of the caravaca cross, placed on a star-formed table at the centre of the ritual room. This cross of two horizontal arms symbolises the second coming of Jesus Christ to earth, which according to the Santo Daime members has arrived for the second time in the body of Mestre Irineu.

Like Mestre Irineu, many of his first followers had experienced both the boom and the hard years following the decline of the rubber industry. The biography of the movement's second main leader, Sebastião Mota de Melo, well represents this common trajectory of rubber tappers in southwestern Amazonia. Born in 1920, in the midst of the collapsing Brazilian rubber market, along a small tributary to the Juruá River (an affluent of the Amazon River, located to the west of the Purús River), Sebastião had early in life to learn how to make a living from scarce resources.

Unlike many others, Sebastião and his family did not abandon the forest when the rubber market collapsed in the 1920s. Instead, they stayed on and when Sebastião was in his twenties, the Brazilian rubber industry experienced a brief recovery as a result of the Second World War. Fearing that the war would cut off their access to the rubber markets in Southeast Asia, the United States and their allies turned to Brazil, and once again Brazilian rubber became a valuable export product. However, the local people were unable to meet this new demand and more manpower was needed. As had been the case during the previous boom, the Brazilian government solved the problem by recruiting thousands of people from the poor and drought stricken Northeast. This second wave of Northeastern immigrants has commonly been referred to as the 'rubber soldiers' (soldados do borracha), because many of them had to choose between either going to war or going to the Amazon.

When the Second World War ended, the Southeast Asian markets reopened and the Brazilian market collapsed once again. As a result the economic situation of the rural Amazonians worsened and people like Sebastião and his family, who had earlier managed to stay on in the for-

During other rituals the members use the 'white dress' (farda branca). Females dress in white skirts, white blouses, white stockings, and white shoes. In addition, females dress may include small green skirts over the white skirts, green ribbons over the shoulders, and colourful bands hanging from the shoulder. Besides this they also wear small silver crowns on their heads. Males dress in white suits, white trousers, white stockings, white shoes, and a navy blue tie. 
ests, now also abandoned their homes in the forests and migrated to urban areas. In 1958 Sebastião, his wife and their children, left Juruá for the first time in their lives and headed down to the town of Rio Branco in Acre.

Sebastião, who for some years had suffered from what he thought was an incurable liver disease, eventually found his way to Mestre Irineu, now a famous and well-respected healer in Rio Branco. After being cured by daime, Sebastião decided to become one of Mestre Irineu's followers and after some years he began to receive his own hymns which encouraged him to start a Santo Daime centre of his own. With permission from Mestre Irineu, Sebastião made his centre at Colônia Cinco Mil, some kilometres outside Rio Branco, where he lived with his family. With the death of Mestre Irineu in 1974, the Santo Daime movement was left without leader. However, there were several candidates for the succession, all of whom claimed to have been divinely appointed, and among these was Sebastião. Subsequent internal disputes eventually resulted in Sebastião's group breaking away from the original centre of Mestre Irineu. ${ }^{4}$

The Colônia Cinco Mil, the Santo Daime centre of Padrinho Sebastião (as his followers now called him), was during this period a community organised on 'relatively egalitarian terms, with a community warehouse run under a type of primitive Christianity' (Polari de Alverga 1998). A special characteristic, which made this community strikingly different from the other ayahuasca-using centres, was Padrinho Sebastião's openness towards non-local people. Instead of fearing the arrival of new people, and instead of condemning urban 'hippie' youths, Padrinho Sebastião welcomed them. He even initiated his own study of the drugs used by the youngsters, the marijuana plant and the mushroom, in order to see for himself if any of these plants could contribute to spiritual enlightenment. After some time, he concluded that marijuana was a beneficial plant, capable of smoothing the visionary experience received when drinking daime, while the mushrooms had too many negative side-effects.

4 Later several more centres broke away from Mestre Irineu's original centre. Besides these centres, that are, so to speak, the offspring of the original centre, there are also other ayahuasca-using groups in the area. The two most important are the Barquinha (the Little Boat), created by a former follower of Mestre Irineu in 1947, and the UDV, União do Vegetal, an autonomous movement started by a rubber tapper in the state of Rondônia in 1961. The Barquinha is today confined to the area in and around Rio Branco (nowadays consisting of various centres that have broken away from the original centre). The UDV has moved its headquarters to Brasilia and is no more of an urban middle-class intellectual movement and has several branches in Brazil. 
The attraction of new members to the Santo Daime movement can be seen as part of a more general trend occurring in Brazil during the 1970s. The growth of new religious movements in Brazil has often been explained in terms of being an outlet for young, politically and socially motivated Brazilians who were unable to protest in any other ways against the military government that ruled the country between 1964 and 1985 (Guha 2000). Even though such an explanation might help us to understand why young urban people wanted to join a communitarian and religious experiment such as the one led by Padrinho Sebastião, it does not explain the movement's attraction to local caboclos.

In order to understand the caboclos' reason for joining the movement, we have to consider the transformation of the region that started during the 1960s and became more profound in the years that followed. With the initiation of ambitious state-sponsored projects such as the Transamazon Highway and the huge colonising programmes for landless Brazilians, new actors poured into the region. These included new settlers, stockbreeders, national and foreign industrial firms, and gold prospectors, all of whom contributed to the rapid and often devastating transformation of the Amazon area. ${ }^{5}$ Uncontrolled felling of forests (in order to create huge grazing areas for cattle and monocultures) radically transformed large parts of the Amazonian landscape, leading to the destruction of forests and biodiversity.

This rapid and exploitative transformation had, however, not only severe ecological consequences but social costs as well. Suffering and misery among the local Amazonian population was further intensified with the many land conflicts between, on the one hand, the local population (Amerindians, caboclos, and rubber tappers) and, on the other hand, new immigrants (settlers, cattle ranchers, industrial companies). This was an unfair competition in which the strong and wealthier actors had the upper hand over the economically and politically weaker locals. During the 1970s and 1980s violence connected to land issues intensified, reaching its peak with the murder of Chico Mendes in 1988, the famous Amazonian ecologist and leader of the rubber tapper union.

I argue that it is only by taking this larger socio-political context into account (often the cause of a kind of structural violence against the caboclos)

$5 \quad$ Paul E. Little (1997: 5) describes Amazonia as a perennial frontier and claims that the frontier process in Amazonia has never been characterised by a massive immigration restricted to one period. Instead it is a continual process, which has taken place in diverse parts of Amazonia. 
that we can understand the caboclos' reasons for joining a movement such as Santo Daime. Although many of them probably turned to the Padrinho Sebastião's community because they hoped that daime would cure their illnesses, there were also those who stayed on and became permanent members. For some of them, a community such as that of Padrinho Sebastião, where people lived and cultivated the land together, must have appeared as a safe alternative in comparison with the option of living alone on small pieces of land that at any time could be invaded by wealthier and often armed land prospectors. Such an explanation also enables us to understand why those who joined the movement during the 1970s did not hesitate to contribute to the common good of the movement from their own resources, be these sums of money received from selling properties or other kinds of possessions.

\section{The Coming of Tranca Rua ${ }^{6}$}

Up to the end of 1970s, the community of Padrinho Sebastião was a rather peaceful place with around 150 members who owned and worked the land together, trying their best to avoid confrontations with wealthier landowners. But the land was hard to cultivate and the members had to devote a lot of time to it. With the steadily increasing prices of food and goods they could not afford to buy tractors and other equipment needed to improve cultivation (Fróes 1986: 61).

Although situated some distance away from the main city, Colônia Cinco Mil was far from being secluded from the outside world. Sick people regularly visited the community, coming from Rio Branco and other places. The openness towards new groups of people (particularly the hippie youths mentioned above) also made the police attentive to the doings of the members and in 1981 the federal police entered Colônia Cinco Mil with the aim of destroying the members' marijuana cultivation (MacRae 1992: 74).

It was at this time, in the midst of these events, that Sebastião started to receive spiritual messages urging him to leave the area and move the community further into the Amazonian rainforest. It is possible to interpret this move of the mother community as a way for members to avoid the kinds of conflicts they had had with the police and wealthier landowners.

6 The story of Tranca Rua is a story familiar to many Santo Daime members. In what follows, I try to remain close to the story as it has been recorded by another member, Alex Polari de Alverga (1992: 123-32). 
However, if we take a closer look at a special event leading up to the move of the mother community, we will get a slightly different picture of what happened. Together with the spiritual messages that urged Padrinho Sebastião to leave the area, Padrinho also received messages that warned him about the coming of difficulties. In one miração (daime experience), he found himself walking along a road when he suddenly realised that a horseman dressed in black was following him. For every step Padrinho took, the horseman got closer and at the end of the road the two met. In another miração, he met a saci, ${ }^{7}$ a small one-legged black coloured spirit smoking a pipe. The spirit leaned against him with all his force and threatened Padrinho, saying that he would make him run away from the Santo Daime doctrine. In yet another miração, Padrinho encountered a huge black man who predicted that he would undergo a test and promised that if he managed to pass it, he would develop further in spiritual knowledge. In order to prepare for whatever was to come, Padrinho continued with more fervour than ever to perfect the rituals.

One day a stranger arrived in Colônia Cinco Mil. He was a black man who came originally from Ceará in Northeastern Brazil, and Padrinho immediately recognised the man as the horseman whom he had met on the road in the miração. He also sensed that this man was a medium skilled in sorcery. Later Padrinho explained to his followers that the man from Ceará had showed up in the community because he felt attracted to the light of daime, a light that he at the same time felt jealous of and wanted to put out.

The man from Ceará was a very talkative person and he explained that he had come in order to remove all the falsehood that he knew was present among Padrinho's followers. Padrinho, who took pride in accepting all kinds of people, invited the man to join the rituals. Although accepting the invitation, the man had no intention of drinking daime because he said that his chief spirit (called Tranca Rua by members) did not allow him to do so.

Soon the man began to conduct his own rituals within the community, some lasting several days. Padrinho did not stop him because, upon the man's arrival, he had received another spiritual message saying that he should let the man act freely within the community for five months. So Padrinho began to observe him without interfering, an act that Padrinho considered to be a form of charity towards both the man and the spirits 
that the man was believed to have brought along with him. By allowing them all to stay, Padrinho hoped that they would finally become attracted to daime. More than anything else he hoped that Tranca Rua, the chief spirit, who obviously acted as a kind of guide to the man, was finally to submit and stop working on the side of evil.

After some months the man from Ceará said that some of his spirits wanted to drink daime, but that this request did not concern Tranca Rua, who still refused. After taking daime, the spirits began to reveal many unpleasant things that were going on in the community. This stirred up emotions among members. Even though the spirits actually were revealing the truth, as Padrinho later explained to his followers, the spirits also found pleasure in making people sad, frustrated, suspicious, and even afraid of one another.

The encounter between Padrinho and Tranca Rua was formulated in terms of a struggle between the good and the evil. When the five months had passed, the man from Ceará finally asked for daime to drink, something that was interpreted as a defeat by members. Twenty minutes after having taken daime, the man began to 'see' (mirar), revelations that Tranca Rua (being within the body of the man) was forced to attend as well. In the middle of a miração, the man suddenly announced that he had seen enough. He left and three days later he was found dead. Padrinho Sebastião's son (and the present leader of the movement), Padrinho Alfredo, later said that these three days were what was required in order to hand over and indoctrinate all the man's spirits. Upon the death of the man, Tranca Rua was left without a body. As the spirit was still in need of one, he entered the body of Padrinho Sebastião who now was obliged to continue the healing work of Tranca Rua.

Soon after this incident Padrinho shifted the mother community from Rio Branco to the interior of Amazonas. The period that followed was extremely hard for both Padrinho and his followers. Not only did they encounter various difficulties in clearing the virgin forest to establish a new village and new areas for cultivation, but in the midst of all this Padrinho also became severely sick. According to the members, this was the result of his battle with Tranca Rua, who manifested himself forcefully in the body of Padrinho, making him among other things cough up balls of blood. After some time Padrinho stopped coughing, but according to Tranca Rua, this symptom would return as soon as there was disharmony among Padrinho's followers. He also accused Padrinho's followers of being 'touchy' and said that this would eventually kill both him and Padrinho.

In order to appease the spirit, members continued with rituals and the 
singing hymns. Then one day, after having nearly killed Padrinho Sebastião, Tranca Rua said to Padrinho Alfredo (the son of Padrinho Sebastião) that he was ready to give up. 'If you accept me as a brother, I will protect this "house" [meaning the spiritual house of Padrinho Sebastião]. The proof of this will be that the old one [Padrinho Sebastião] will regain his health.' Padrinho Alfredo immediately answered that 'if you give value to our remedies and to the daime, we will accept you as a brother' (Polari de Alverga 1992: 130-1, my translation). After this Padrinho Sebastião regained his health and it is said that from this moment Tranca Rua turned into a spirit working for good instead of evil. In fact he is now even said to be the chief protective spirit of the Santo Daime movement.

The spiritual work that had been done in order for Padrinho Sebastião recover his health (and to put Tranca Rua on the path of daime) resulted in the formation of a new kind of ritual, Trabalho da Estrela (Star Work), dedicated to the healing of suffering spirits. The aim of this ritual is to bring light to suffering spirits, something that members claim can only be done through loving even the worst kinds of negative and violent beings.

This event also made members realise that people, like the man from Ceará, who from the beginning might appear to be destructive, in fact have an important and instrumental role when it comes to disciplining members. According to a man called Mário,

These aparelhos [speaking about the body of those who receive spirits] that seem to work against us are in fact our judges. We should not fail to recognise their role. They are the ones who come to charge us. They are the ones who demand the bill and ask, Well! But your life is holy? Then why are you afraid? (Polari de Alverga 1992: 132, my translation.)

A similar way of reasoning is also present today when people talk about the 'spreading of bad news' (correio da má notícia), that is, people who spread bad news about the movement and its members. According to members, by 'spreading bad news' people are in fact enhancing the power of troublesome and malevolent spirits, something that eventually will lead to mistrust, destruction, misery, madness, and sickness. By its prolongation, correio da má notícia will cause fear and doubt among people and also attract additional spirits of fear and doubt. Although correio da má notícia is commonly spoken about in negative terms, as something that people ought to avoid, Polari de Alverga claims that it sometimes also signals the coming of good news and the revelation of truth (1992: 52). The present leader, Padrinho Alfredo, has even suggested that correio da má notícia should be 
treated as a divine spiritual being who appears in order to test the faith of members. ${ }^{8}$

Hence correio da má notícia has a double message. On the one hand, the spreading of bad news is something unwanted. But, on the other hand, it is also something that members are encouraged to look upon as a positive force, signalling either the coming of something good or the coming of a test. The story of Tranca Rua, which at first sight might seem to be about handling or controlling negative energies that threaten to cause confusion, uncertainty, and uneasiness, is in a similar vein, a story about the power of the negative. What is at stake here is not only the transformation of the negative into something positive, but also the acknowledgement of the negative as a positive power, capable of revealing and condemning the wrong doings of Santo Daime members. Here Tranca Rua even uses the symptoms of Padrinho Sebastião's illness (represented by the coughing up of blood) as a means to control members' behaviour.

It is true that the move of the mother community, which occurred at the same time as Padrinho Sebastião's encounter with Tranca Rua, can be interpreted as a way to avoid conflict and violence. However, if we only interpret what happens as a withdrawal from violence, we would easily miss other aspects that point in the opposite direction. Actually, the encounter with Tranca Rua is also about the development of strategies aiming more consciously at dealing with conflicts and violence. One practical consequence of the meeting with Tranca Rua is, for example, the formation of a new kind of spiritual work called Trabalho da Estrela (Star Work), rituals that developed through the hard work of putting Tranca Rua on the path of daime. Today this healing work aims not so much at healing the suffering individual, but more to the healing of the suffering spirits (espiritos sofredores), spirits that according to members are the cause to all kinds of conflicts, misery, and illnesses in the word. The healing (and transformation) of such spirits has today even turned into a moral practice that members ought to engage in not only during the rituals but in everyday life as well.

In order to understand the importance given by members to this moral practice, we must first take a closer look at members' perception of the self. According to Santo Daime members, human beings have a Higher Self. This is a self that exists above and beyond the 'ordinary self' of everyday life. By drinking daime people are said to be able to approach and 
experience this Higher Self and also learn more about how this self is concealed in everyday life by the ordinary self. This latter self is not the true self. Instead, the self that people experience in everyday life is said to be a self more or less governed by different kinds of spiritual beings. Many of these spirits are so-called 'suffering spirits' that continuously manifest themselves through the thoughts and emotions of individuals.

The main aim of the ritual called Trabalho da Estrela is to work with suffering spirits by healing and transforming them into more benign beings. Daime plays a very important role here as it enables the members to see and experience the spirits during the ritual. It also helps the individual to understand that whenever a negative spiritual being manifests itself through an individual's thoughts, that individual has the responsibility to transform negative thoughts into more positive ones, or in the language of members, to transform negative spirits into more positive ones. This act requires that members learn how to discipline the mind. Although it might be supposed that the purpose of all this is to enhance the well-being of the individual, this is not actually the case. The well-being of the individual is in fact only a side-effect. What really is at stake here is the well-being of the spirits. The encounter with Tranca Rua therefore represents a change in focus. From now on the well-being of the spirits is of equal importance to that of human individuals.

\section{Santo Daime Morality Turns into an Environmental Necessity}

It might look like a paradox, but it seems as if the extended solidarity with the well-being of the spirits is actually what has enabled Santo Daime to change from being a purely religious movement, with the aim of healing sick individuals, into an environmental movement. By broadening their 'vocation' (moving beyond the individual), members have in fact managed to develop a strategy that has a much more worldly moral implication.

Let me explain. Even though Santo Daime morality is still fostered and shaped through the drinking of daime in ritual contexts, non-ritual arenas have in recent years acquired an increasing importance when it comes to practising and perfecting this moral attitude towards life. Today, working and being actively involved in some of the village's many ecological projects has actually turned into an important 'sign of engagement'. To a great extent working with environmental issues has become synonymous with being spiritually evolved, with being a committed Santo Daime member. 
The work done within the projects has many similarities with the work done during the rituals. The most obvious similarity is the stress on the necessity to discipline the mind while working (something that is said to be crucial for transforming negative spirits), which often involves the singing of Santo Daime hymns. However there is also a major difference between these two 'working realms' and this is the absence of daime while working within the projects. Hence one could argue that more worldly environmental work has become an extended form of spiritual work.

The kind of moral practice that once began as a way to deal with the threat of conflict and violence has today turned into an enduring strategy that permeates members' undertakings in matters related to environmentalism. Not only has it been crucial in shaping a new lifestyle among members, centring as it does on environmental concerns, but it has also moved the Santo Daime movement closer to more 'worldly' actors concerned with the future of the natural world. Although by sharing a common cause with such interest groups, Santo Daime members have been able to do so without loosing their distinct identity as members of a religious healing movement.

It is possible to argue that Santo Daime has reconnected the physical and, if one wants, the secular through their efforts to re-moralise and respiritualise the world. Eventually this has enabled its members to move beyond a purely anthropocentric and individualistic approach to salvation, by also including in their idea of salvation a sincere concern for the fate of the world.

\section{References}

\section{Farmer, Paul}

2003 Pathologies of Power: Health, Human Rights, and the New War on the Poor. Berkeley, Los Angeles, London: University of California Press.

Fróes, Vera

1986 Santo Daime: cultura Amazônica - história do povo Juramidam. Manaus: Suframa.

\section{Gow, Peter}

1994 River people: shamanism and history in western Amazonia. In: N. Thomas C. Humphrey (ed.), Shamanism, History and the State; pp. 90-113. Ann Arbor: University of Michigan Press.

\section{Guha, Ramachandra}

2000 Environmentalism: a Global History. New Delhi: Oxford University Press. 


\section{Little, Paul E.}

1997 Superimposed cosmographies on regional Amazonian frontiers. Brasília: UnB.

\section{Luna, Luis Eduardo}

1986 Vegetalismo: Shamanism among the Mestizo Population of the Peruvian Amazon. Stockholm: Almqvist \& Wiksell.

\section{MacRae, Edward}

1992 Guiado pela lua: xamanismo e uso ritual da ayahuasca no culto do Santo Daime. São Paulo: Editora Brasiliense.

Polari de Alverga, Alex

1992 O guia da floresta. Rio de Janeiro: Editora Record.

1998 Spirituality, ecology and the forest. The experience of a spiritual community in Amazonia. In: Maria de Lourdes Davies de Freitas (ed.), Amazonia. Heaven of a New World; pp. 289-97. Rio de Janeiro: Editora Campus.

\section{Scheper-Hughes, Nancy}

1992 Death without Weeping: the Violence of Everyday Life in Brazil. Berkeley, Los Angeles, Oxford: University of California Press. 